\title{
Disasters, tourism and mobility, the case of Japan earthquake
}

\author{
Maximiliano E. Korstanje* \\ University of Palermo, Argentina \\ Peter Tarlow \\ Texas A\&M University, United States
}

\begin{abstract}
It is not uncommon to note that during emergencies or natural disasters a number of socio-psychological triggers come to the forefront so as to help the public the event and place it in a comprehensible context. Without these socio-psychological triggers the public would be left not only in an anomic state, but social disintegration would begin to set in. One way that we begin to sort out and make sense of these negative tragedies is through the twin social mechanisms of nationalism and consumerism. During moments when societies must face potential exterminations, survival may occur through the strengthening of individuality and group identity. These two social phenomena act as antidotes to the tragedy and allows for group survival. Thus after a tragedy such as a tsunami or earthquake, national (or group) pride permits the social healing process to begin. It is against this backdrop that we analyze the media coverage and the reaction of the Buenos Aires Japanese community to the earthquake and tsunami that decimated Japan in 2011 and the dangers that ensued from the damage to the Fukuyima reactor. Although this work is about one small community within the Japanese Diaspora, it serves its social psychological insights are not confined to this community but rather should be replicable throughout the world.
\end{abstract}

Key words: Culture, Earthquake Fear, Risk, Travel, Tourism,

\section{Introduction}

At 2:46 pm on March 11, 2011 Japan suffered one of its most intense and devastation earthquakes. The earthquake measured some 7.9 on the Richter scale. It was so intensive that world's media provided almost non-stop 24-hour news coverage. The reports spoke about the number of victims, and behind the reports the "ghost of a Chernobyl-like nuclear disaster" was ever-present. The earthquake followed by a tsunami not only devastated the Japanese coast but also posed a serious risk should Fikushima nuclear reactor suffer a meltdown. Such a meltdown was more than a serious threat to life; it also was symbolic in that:

a) The potential for a nuclear accident or worse now became a real possibility, such a possibility made the public aware that what occurred in Chernobyl might be repeated. This potential nuclear threat dominated the public's anguish.

b) No one was sure what would be the negative results on the locale's children

* E-mail: maxikorstanje@arnet.com.ar 
c) Humanity once again had to note that in the face of the earthquake and tsunami it was powerless.

d) Television viewers saw the harm that nature had done both on the land and on the sea.

e) Television viewers in other countries realized that no one was immune from the uncontrollable effects of a natural disaster, thus viewers once again noted their impotence in the face of natural disasters. For example, the mass media showed pictures of water invading Japanese cities and destroying all that lay in its path.

f) The media's emphasis on personal "miracles" not only reinforced the notion of impotence in the face of natural disasters but also introduced an element of the mystical into the tragedy. Media reports of people who saved their lives against all odds served not only as examples of the exception to the rule, but also introduced an element of humility into the arrogance of modernity. Science simply could not solve everything and once again we noted the concept of machina ex deus

g) The story was brought home by eyewitness accounts of other visitors to Japan

E. Quarantelli (2006), a senior sociologist who devoted his life in themes of disasters, revealed that the way lay-people perceive the world has changed. To the classical disasters whereby cinema narrates its stories, another type of new virtualized disaster has taken place. The latter one signals to events which never happened in reality. Based on suppositions, speculations and hypothesis (risks), these new types of mediated disasters have become in a cultural entertainment, as never before. Quarantelli's upshot led Korstanje to argue we are living the end of resiliency because our ability to learn from events is being undermined (Korstanje, 2011). Any virtual disaster not only set the pace to other, but the boundaries between reason and cause is being blurred. More apocalyptic, more intriguing, more striking the virtualized disasters poses a serious challenge for Science in the next millennium. A careful review of the media accounting of natural and manmade disasters demonstrates that the media often has its own agenda. For example, although denied, a careful observer will note that the media's experts often seem to have predetermined roles. These "scripts" demonstrate that the media hosts not only guide the expert's message, but should the expert go off script, then s/he faces being cut off. Media personalities not only control the microphone but also give themselves a sense of selfimportance. Thus, news often becomes a spectacle in and of itself. Television reporting often becomes a mixture of sensationalism mixed with scientific truth in which media personalities create an apocalyptic image. The report leaves the viewer with the sensation that: "the worst is yet to come". If we apply this principle to the case of Japan, we note of how the media spoke about the possibility of a "nuclear Armageddon." However, just as in the majority of other disasters stories, the case of the potential "nuclear catastrophe" may have had us on the edge of our seats for a while, but then it vanished as the media turned its attention elsewhere.

Undoubtedly, one of the philosophers who have devoted his attention to the study of fear and media was Jean Baudrillard. His legacy poses the question in a serious debate considering not only how reality is built, but also how disasters are covered and interposed. His contributions played a pivotal role in what Korstanje (2010) called the emergency of a new resilience in the study of disasters and culture. Stimulating a fertile ground to discuss to what an extent the media created a parallel reality, enrooted in the uncertainty of future, Baudrillard reminds that the absence of a clear diagnosis of reasons that ushered communities to a state of emergency, it is impossible to conduct success plans of risk-mitigation. Even, any attempt to reduce risks in the real, will create new unplanned risks (principle of reversibility). Secondly, the attacks perpetrated against the World Trade Center represent the success of the individual being, over the world of cloning. WTC or twin towers are alike, as cloned from the same model. Any suicide exhibits the last individual effort of self-annihilation in the world of hyper-reality. Like buildings, news are copied and distributed to a broader audience, which is pressed to live in an eternal present. If causes and effects are blurred in the same setting, one disaster will set the pace to the other undermining our capacity to learn of tragedies. National-being and patriotism play a pervasive role, Baudrillard admits, because for one hand it achieves the social cohesion in context of uncertainty or emergency, but on another, it gives the blindness enough to the disaster to be repeated again, and again.

In this paper we present culture and travel as two important elements in trying to comprehend the relationship between disasters and consumption. By means of content analysis as a 
principle methodology, this study uses a letter sent by the FCAJ (Spanish acronym for "Argentine - Japanese Cultural Foundation") with its main offices in Buenos Aires' Japanese Gardens district. In the letter the FCAJ invited its members to make a cultural journey to Japan soon after the earthquake. This essay uses this letter to explore the different narratives that comprise the cultural axis of a trip; an aspect rarely studied within the academic literature. Tourism philosophy is presented as a useful tool to figure out questions attached to the symbolic elaboration of misfortune and how tourism deals with human and natural misfortunes.

The main thesis in this work is that both, tourism and nationalism operate as ideological instruments so that the nation not to be fragmented. Beyond the trauma and suffering, the survivor develops an exaggerated self-image that leads to ethnocentrism and chauvinism. After all, survivors have passed the proof of death. Their invulnerability is often accompanied with stories linked to the strength, fate, pride and courage. This sentiment, which at a short-run, helps people to overcome the wounds postdisaster, at a later day becomes in a iron-cage because upends the causes and consequences of the event. As a result of this, the responsible for the event elude their culprit. As Baudrillard put it, in a world where the events has been emptied and transformed in pseudo-events, disasters are commoditized to entertain a much broader audience.

\section{Travel as an attraction}

Currently travel and mobility have been transformed into two of modernity's complementary activities. This activity suggests that not only has travel increased but also the speed in which we travel has increased. Connected to this increase, but not necessarily due to it, humanity's capacity to transmit information across the world has also increased. (Lew, 1987; Virilio, 1991; 2007; Urry, 2007; Lash y Urry, 1998; Giddens, 1991; Birtchnell y Buscher, 2011). This increase in both the transmission of information and the increase in travel, while not irrevocable, is hard to stop. Although governments in countries such as China, Iran, and Syria have worked hard to stop the flow of information, their populations have found new and innovative ways to absorb the ever-increasing flow of cross-border information. Often the number of trips made have to do with types of dangers associated with the place to where the trip is to be made or the type of trip. Dangers may include such things as: terrorism, diseases, crime and natural disasters. However, the (tourism) trip also functions as a place where fear and social (class) distinction converge. (Douglas 1997). There is no trip without the possibility of an accident (risk). Despite the risks involved, people do not shy away from travel because they falsely believe that they can avoid all risks. It should be noted that the risk of accidents, and above all it's the inherent thrill of danger, is a determining factor in how adventurous a trip is perceived to be. This is one reason that people may travel to places that are known for being off the beaten path. For example, a volcano's eruption may constrict demand for visiting a specific locale for a while, but once the danger has been removed the destination often becomes even more popular. Tourism destinations, be they places where there have been battles, or disasters, or have emerged as a product of a previous accident, often become tourism becons. (Bianchi, 2007; Lennon and Folley, 2000; Korstanje, 2010b; Kaelber, 2007; Poria, 2007; O`Rourke, 1988; Ryan, 2005; Seaton, 1996; 1999; 2000; Urry, 2001; Stone, 2005; 2011).

George, Inbakaran y Poyyamoli (2010) emphasize that tourism is different from a trip of journey. A trip takes us from one place to another, but tourism is circular and the goal is to visit a place and then return, it is a trip that takes us to where we began. One tourism motivation is curiosity and the sense of danger inherent in any tourism experience leads both adventure and excitement. It is a paradox that we search for safe places in which to stay and it is the industry's responsibility to maximize the traveler's security while permitting a sense of danger and excitement at the same time. Elías and Dunning (1992), on the other hand, note that we classify business or pleasure trips by a sense of controlled environment that separates us from fear. A limited dosis of fundamental risk provides a social distinction. It would appear one aspect of tourism is that it dislocates our sense of belonging and our identity by placing us in an anomic situation in such a way that systems. need to be established that allow for accommodation to the new environment. (Tang y Wong, 2009).

The German philosopher C. Wenge proposes three theories to explain the reasons that we travel. According to Wenge we travel because: a) we seek to evade something, b) we seek some form of status or c) we go on a pilgrimage. In the first case, the idea of avoidance or evading, Wenge suggests that we seek to travel to sepa- 
rate ourselves from life's routines and drudgery. The traveler then seeks relief from work that both "alienates and oppresses". Using this perspective, we see a converging of the aspiration for something new with the desire to get away from life's daily routines. On the contrary, the thesis of conformity or status explains that we travel to fit into the norms of the dominant class from which comes the ostentatious consumption of experiences and social recognition. Finally, travel as pilgrimage rerefers to the need for movement and implies obligation and exhibition. In the modern world pilgrimages often interconnected with messages that the media send forth, thus what we read in a novel or see on television or the movies becomes a tourism pilgrimage, be that pilgrimage of the secular or religious variety. For example, a visit to many of the monuments in Washington, DC can be seen as a secular pilgrimage. In a like manner many people wanted to visit the train station from which Harry Potter left for the mythical world of Hogwarts School of Witchcraft and Wizardry or the churches mentioned in Dan Brown's Da Vinci Code. (Wenge, 2007). Wenge does not clarify if his pilgrimage thesis is due to a necessity of underlining the "faults" or an exhibitionist form of being different. On this point Korstanje and Busby (2010) have explained the origin of tourism may be from the Biblical texts where the sin implies a movement outside of the norms as a form of evasion of responsibility. In the Hebrew verbal root for the verb "to sin: (chet-tet-alef) literally means to miss the mark or for the arrow to miss its target.

In agreement with the above authors, S. Larsen introduces a new category which he calls "worry" as a form of normative reinforcement. Worry is an inference that transcends the cognitive field exclusively with the appearance of probable results and coupled with a person's or group's negative energy that created a desire for travel, thus worry is related to danger. Furthermore, as worry increases; there is a decline in our willingness to assume risks. For this reason travelers have greater worries when they are at home imagining their trip in comparison to when they are on a trip. (Larsen, 2007; 2009). In the last decades, professional advice has become a way for people to seek an efficient way to put outside threats intellectually understandable context. The travel professional has been become the go-to person in order to obtain technical advice and to measure risk. Professionals are precisely those who are empowered by society (or in some places the state) to protect individual's lives maximize earning and reduce dangers. (Bledstein, 1978; Beck, 2006; Bauman, 2008).

In the case of tourism, the professional's familiarity with potential dangers sends a reassuring message to the client giving her/ him a certain sense of security that s/he can take on the trip. (Fielding et al, 2005). Moving beyond the field of travel we note that Sjoberg considers that there exists a differentiation in the way in which an expert analyzes a threat with respect to public opinion. For example, a professional who is dedicated to a nuclear threat will view the threat through the lens of his knowledge base and in a different way from that of someone with a lesser knowledge base. This type of knowledge is often called "High knowledge" rather than low knowledge. A person may have high knowledge in one area but in other areas only The author admits that there is no consensus in the literature. For example, there are studies that demonstrate in the field of medicine that doctors and patients perceive "high levels of risk" in the face of high potential illnesses. According to Thomas Kuhn, (The Structure of Scientific Revolutions, 1962) experts are often committed to their paradigm and therefore hold onto this belief with a high level of confidence, To be an expert is to believe in one's ability to grapple with and seek ways to treat the problem. Politicians, on the other hand, must react to public trends and therefore tend to hold much lower confidence levels.

There are two roles that expert plays in the management of risk, protector and promoter. The first type refers to the professionals who are part of the public information services with the goal of informing the public so as to avoid states of emergency. The "protectors" tend to be upset that the public may have scarce information about a determined risk and these experts will put their efforts into shaping the debate regarding specific societal questions (for example, doctors, first aid workers or experts in natural disasters). This desire to shape the debate may mean that the so-called "experts" at times become part of the problem. In much of the population there exists the perception that there is a relationship between technology and risk, a pessimistic perspective which signals that technology is responsible for the risk.

\section{Risk and Technology}

The sociologies of Beck and Giddens have examined the relationship between technology and 
risk. From Beck's perspective, a societiy's means of production is ever changing even when it is in the world of "as if or might be". Beck argues that societies feign practices and customs from previous decades, even when the market and its forms of production have changed direction. In the social world we observe a preliminary state that stands between an industrial society and a risk society. The globalization of risk assaults the individual's integrity. Beck is conscious that the process of modernity regressed soon after the Chernobyl accident in the Ukraine. Chernobyl altered radically the way in which we perceive risk and threats. These post-Chernobyl risks differ from the risks that medieval travelers faced. The medieval traveler evaluated his personal risks before setting forth on his/her adventure. Modern risks on the other hand are presented not on the micro scale but rather on the macro scales as: global risks, world catastrophes and chaotic situation in which the traveler is enveloped into a sense of impotency. (Beck 2006).

According to Beck, minor threats or individual risks eventually become tolerated by society, but as these risks accumulate they become major threats. For example, the random murder of innocent civilians by terrorist groups in places such as Israel is often tolerated by the word, but when the numbers become such that Israel must take action, then the individual tragedies of rocket attacks on school children become international threats to world peace and the United Nations becomes concerned. The saying that the destruction of even one life is the destruction of an entire world has now been lost to the modern media. In this way, as opposed to the business class that maintains a strict line of separation between economic classes, modern society confronts a new configuration in its social order. This new society receives the name "a risk society" whose principal characteristic lies in the risks that are equally distributed throughout the classes and social groupings. Against the logic of material appropriation of merchandise, we now are presented with the antithesis: the logic of denial. Partially, by means of journalism or science privileged-groups hide information with regards to risks and minimize the collateral damage produced by hyper-consumption. Thus, the responsibilities and the rights blur the borders between innocence and culpability. From this perspective, risk production is proportional to the distribution of wealth. Beck's sociology's main thesis is that the imposition of risks on the consumer involves the idea of a limited stimulation by the market. From this perspective, fear is the only necessity that has no end point and there is always room for more (Beck, 2006). Consequently, as production increases then so do risks.

Anthony Giddens proposes to understand modernity and technology as an epistemological break that is divorced from the ideals of the illustration even to the point of creating fragmentation and uncertainty. According to Giddens, capitalism needs a degree of risk to maintain its raison d'être. The mediation of capital fulfills a primordial role in the configuration of risk as it absorbs the dangers derived from fear. For example, an insurance company that assumes third party risks as its own demands a specific amount of money as compensation. Traditional societies are nourished by trust in the past while at the same time blurring the past. In a like manner, modern technology has eroded on of the other basis of trust, religion, even to the point of transforming itself into its own god. Thus, we observe that experts have replaced priests in the selling of fear. In the Christian world the notion of "hell" has been replaced by modernity's use of risk. Thus experts work around this notion in a discourse of risk (Giddens, 1991; 1999; 2000).

According to Leo Marx the conception of technology during the Enlightenment began to change radically with the arrival of modernity. With post-modernity, the idea of progress and moral reform, the enlightenment created a utopian ideal with respect to progress. However, technology played a limited role in its relationship to this ideal. Technology and fear did not fulfill its own ends. With modernity, the relationship became reversed creating a "technocracatic/technological" truth in which technology begins to gnaw at the enlightenment's ideals. Post modernism criticizes the use given to technology by the Enlightenment; nevertheless, postmodernism's argument is summed up as dogmatic and authoritarian. Postmodern critics argue that if these goals rest only in the technical then these goals are amoral and irrational in and of themselves. From its creation, soon after the French involvement in its Vietnam War, postmodernism has been pessimistic regarding the use and role of technology. This questioning of technology is one of the concepts that this movement rejects. As such it rejects not only the Enlightenment's ideals concerning technology, but also in the narrative constructed around the notion of historical progress. Nevertheless, there is an internal contradiction in that postmodernism offers a much more technological vision than that which it aims to destroy. This 
contradiction holds especially true in the excessive role that the communication industry has taken in this process. In its diehard criticism of ideology and the system of ideas, postmodernism demonstrates multiple contradictions (Marx, 1994: 25).

R. Pippin expands this line of reasoning when he writes, if the first Marxists (including Karl Marx) considered technology as a leap backwards in the course of a society's progress, it was after the intervention of Lukacs and especially after the Frankurt school that technology was begun to be seen as an instrument of alienation within Capitalist sociology. (Pippin, 1994: 99). On the other hand, it was clear that technologies, such as medical technology, firmed up dominant groups with respect to risk. Nevertheless, it is undeniable that with the decline of technology we have seen the decline of the basis of scientific authority. The fragmentation (called specialization) of knowledge accompanied by a strong no one set of established norms resulted in an increase in each society's threshold of uncertainty. The fear is determined by the degree of narcissism developed by the self.

According to Lasch, there exists an almost irreversible tendency to conceive of the external world as dangerous, catastrophic and/or chaotic. This tendency is a product of a valueschange and cosmic vision that appeared for the first time in Modernity. The current situation in which, despite the political rhetoric, no one really seeks a solution to problems that can take us to a state of catastrophe, but rather stress individual survival. Lasch argues that in a narcissistic culture that characterizes the "I" it is hard to understand the future of the "we". Modern man shows a great deal of disinterest in the past and above lacks a sense of tradition. The past only represents in a narcissistic culture a trivial form of commercialization and exchange (see cultural patronizing). While, fear has been converted into a way for therapists to make money (being empowered to examine this phenomenon), moderns have subordinated all of their inhibitions to the "company" and are incapable of satisfying their own needs. Personal self-fulfillment is presented as the maximum measure of success in a narcissist society. There exists an entire cultural critique that holds that psychological therapy tends to indoctrinate the lower classes in upper class goals, such as personal development and self-control. Modern society and its productive system appeal to division of social relations and subsuming them before technical and expert dominance (Lasch, 1999)

\section{Spectacles and Cultural Dominance}

Scaremongering, explains E. Berbeglia, comes out of a double tendency to reconcile opposites. On one hand, there is fear, while on the other hand there is hope. Both stake their claim in reconstructing a new form of linkage between members of a society. The imposition of panic by means of multiple mechanisms is complemented by political messages whose ultimate ends are indoctrination and control. If on one hand, scaremongering emphasizes worst-case scenarios, on the other hand it provides sufficient security to present a solution to the problem. In this way, threats that promise to destroy civilization converge with possible solutions that are presented by Science and the Community of Experts. Catastrophes imply a cultural rupture (produced by human intervention in nature or by nature itself) in which humans either adapt or perish. Catastrophic events generate discussions that serve as warning and alternate between hope and fear. For those who follow plans, such as evacuation plans there is hope and for those who choose to ignore these plans or disobey them fear is ever present. Examples of this hope/fear continuum are hurricane warnings given along the US's Gulf Coast. Residents are routinely told to follow evacuation orders or they risk death. The Katrina disaster that struck the city of New Orleans in 2005 versus this year's hurricane season with the arrival of hurricane Isaac demonstrates the political symbolic construct of a disaster (Berbeglia, 2002).

Another scholar, S. Zizek (2011) discusses the paradox of a modernity in which certain things are permitted, but only when they link people with mobility and technology but prohibit other things, when this same mobility leads us to question the precepts of capitalism. Thus, our world allows us to get to the moon as tourists, we can travel more rapidly and comfortably, but it is not permitted to break with the ideas of the bourgeois or with a distorted idea of modern democracy. In short, experts' roles and the content that they produce generate only serves to aid the market's ideological machinery. In the book Blaming the Victim, William Ryan (1971) validated the belief that some subtle tactics not to face the responsibility for their decisions. Ideology serves as a system of belief that preserves the power of aristocracies or elites, event the injustices many citizens should tolerate day by day. These types of ideas are "a distortion of reality" reflecting intentional purposes. Blaming the victim seems to be an ideological process that distorts the real causes of emergencies. To put 
this in bluntly, if the poverty is a state of disaster, which shows the "inequality of American society", pours are overtly blamed by their socioeconomic conditions. The background or social forces that generate these unfair situations not only are not criticized but also are preserved. The dichotomy between assistance (charity) and subordination is not clear in the Blaming-thevictim strategies. In this respective, blaming the victim happens with exceptionalist frameworks that apply on universal values. To put this in another way, whenever journalists portray that poverty is a reason that leads people to disasters is blaming the victim (Ryan, 1971: 16-17). It is safe to affirm that social problems and disasters play a vital role in configuring the ideological discourse to blame the victims for the events. As ideology, tourism engenders a specific discourse which sometimes is not clear and sometimes is self-explanatory.

If, as Baudrillard surmises, we are living in a time of the decline of the nation-state and of religion, its resurgence can be explained after a natural tragedy occurs. It is important to examine "in how and with what semantic elements" nationalism constructs a discourse e tending to feed its own logic before adversity, chaos, anarchy, and disorders. Nature is neither tamable nor always understood, and we often perceive it as hostile. Yet there are symbols that offer hope in the desolate social and political environment. Hope is often found in symbolism. For example, the figure of the rescue dog trained to save human lives transforms the harshness of nature. The Chilean or Swiss rescue dog inspires patriotism and these nations citizens wave their flags in unison as a sign of pride. Symbols can also be human. For example the Israeli medical teams that came to Haiti's aid before any other nation and within some forty-eight hours had tent hospitals up and running created a great sense of pride in Israel. The theme there was as Europe and the American nations talked, Israel acted. The central thesis is that far from having disappeared, nationalism and the nation-state appear to have been transformed and are doing quite well.

Another example is that Chilean nationalism became activated in the face of the earthquake that occurred there during the end of February (2010) Words as courage, uprising, and battle appear in the testimonies of the survivors as well as in the announcers' voices or those of the commentators who came on the air. The survivor served his/her society by construction a "national feeling" by which s/ he can give testimony to the event. This tes- timony is necessary for the national dialogue that permits healing. The same phenomenon can be found both in both the Jewish world and Germany after World War II. However no such dialogue took place in France and so the nation never healed. France has no equivalent to writers such as Ellie Weisel and only now some 60 years later is coming to terms with its political earthquake.

\section{Jean Baudrillard and the sense of reality}

In post modernity, the event succumbs before the logic of the spectacle, and thus is transformed into a non-event. By transforming the event into a media tale, the story comes to symbolize the lack of real events and becomes the production of non-events. Thus, September 11, 2001 attack against the Twin Towers inaugurated the end of history and the re-elaboration of potentiality (efficiency). The media decided which events became facts and then transmits daily thousands of similar events that numbs the senses and makes the unique common, as noted by Baudrillard. Interestingly this same method is used by academicians who produced so many "scholarly" articles that they succeed in "dumbing down" society. Ever since SARS and until September 11 (2001) the concept of efficiency has created a system of functional non-events for a market that produces ever greater amounts of gradually subjective publicity (Baudrillard, 1995a; 1995b; 2001; 2002). Modern capitalistic society lives under two cultural principles: the proliferation of the computer and a high degree of sexuality as expressed in the media. Threats mobilize resources with the end of legitimizing the social order. AIDS, terrorism, crack deals, electronic viruses put into play a process whereby society examines a whole series of processes and speculations that it may have on one of these subjects.

The event creates a break between "the before and the after", the succession of events are the result of history. Extreme phenomena acquire great virulence to the extent that they falsify human tools that are destined to the examination of the internal world and its surroundings. Baudrillard argues that humans need catastrophes so as not to be lost in emptiness or absolute nothingness. Baudrillard writes: "the total catastrophe would be that of the omnipresence of all information, of that which is totally transparent whose effects are luckily eclipsed by the computer virus. Thanks to it (the virus) we will not go on a straight line until the end of 
information and communication which would be death" (Baudrillard, 2000: 16).

The catastrophe has turned into a kind of tool with the end of avoiding that worse occurs. Emergencies and catastrophes, danger paralyzes our social lives with the objective of avoid a state of disintegration. Global threats function as a virus taken from the physical body, that in this case is a fact or event $\mathrm{X}$ and moves into it to be virtually disseminated to other bodies from which it can infect other organisms. In this way, the mass media functions as a perfect mechanism in the making the disaster spread.

In this respect, the French philosopher writes "electronic viruses are the expression of information's homicidal transparency throughout the world. AIDS is the emanation of the homicidal transparency of sexual liberation on group scales. The stock market Cracks are the expression of murderous transparency of the economy between itself, of the rapid circulation of values that are the base of both liberation from production and interchange. Once liberated, all of the processes enter into super-fusion on the scale of nuclear fusion that is its prototype." (Ibíd.: 42). Given the right conditions, political manipulation proposes an objective, an evil, a problem that only it can solve or exorcize. The superiority of certain groups to define that which is good or evil, is accompanied by an ideological conversation whose maximum tool is the diffusion of fear. However to differentiate from Beck, he admits that we have weakened quite a lot in creating satanic energy, which metaphorically implies that evil has been devoid of its symbolic function. It no longer acts as a deterrent, but in an objective manner a fetish blurring the limits about which we must be afraid. This fear does not have an objective. It is similar to an existentialist anguish. The Western World lives in a protected capsule, not unlike riding in a pressured airplane capsule, and terrorism is implicit the effect of depressurizing. Violence practiced on the East turns against the West each time weaker in its ethical and moral values

In a penetrating, clear and eloquent manner, Baudrillard calls attention to the fact that threats mobilize resources with the end of legitimizing society's order. AIDS, terrorism, financial crack, and electronic viruses put into play a process whereby society reviews a series of procedures and assumptions that touch upon a specific theme. The event creates a break between "a before and an after", and linking these events becomes history. Extreme phenomena acquire greater sensitive virulence to the measure that they become sophisticated human tools destined for the exploitation of the internal and surrounding world. Catastrophes become a tool with the end of avoiding that something worse might happen. The pursuit of manufactured events erases the principle of reality in the mind of the media.

G. Coulter reminds that Baudrillard proposes a new concept of reality originally based on Greek Philosophy, an allegory of the second thermodynamic law. To understand his legacy, one might take attention to the concept of reversibility, which denotes the system-weakness. Any structure, like empires, is subject to the possibility to collapse because of its own strength. If the linear evolution of technology poses the idea of moving forth to a next stage, reversibility evokes the poetics as a form of replaced dialectics. (Coulter, 2012). Of course, as post-structutalist, Baudrillard knows the virtualization of the media blurs the bridge between fiction and truth. Unlike other philosophers, he does not look the truth of events. What today people know about history is by means of movies. Not only, this reveals certain ignorance respecting to the past, but the history has ended. Starting from the premise reversibility is a natural antidote against determinism, Baudrillard argues that poems resulted from ambiguity and uncertainty, which are enrooted in the language. Like truth, language determines the boundaries of being but since any meaning are subject to proper understanding. Alluding to the metaphor of precogs in Minority Report, who anticipated to the crime before it was committed, his most intriguing point of debate is that fiction, like theory, give sense in order for us to understand the world, preceding everything one might feel. The construction of concepts reveals that nothing can be said about events. Therefore, the visual appearances seem to replace the meaning of pastime. The "vertigo of interpretation" imposed by the media, not only was based on an immediate future, but also destroyed the history. As Coulter adds, we are not able to find the truth simply because it keeps covert for human mind, only affordable by means of fiction. However, fiction may not be empirically verified as facts. After all, truth is only an illusory construction designed in order for human beings to reach nothing. To put this in brutally, the truth is as the fish that bites its own tail. Therefore, Baudrillard is convinced that 9/11 never existed. He is not the philosopher of non-sense as some other scholars proposed. The baurdillard's legacy consists in a sharp criticism against modernity and hyper- 
reality, to the extent to defy on the compliance of science with market. Following this, the hyper-reality (media) have been paved the ways to create a show to be sold to an international audience where the reason and effects of disasters are covered. As reality is not necessary in modern times, history has been commoditized to work together nationalism and patriotism. Philosophers should take away distance from the illusory nature of patriotism and tradition. What are the underlying dangers of nationalisms?.

\section{Intellectuals, experts and Nation-state}

It is important not to loose the sight that Baudrillard exerted a criticism against the work of Susan Sontag and Noam Chomsky arguing both intellectuals is moved by certain chauvinist interests. In the case of Sontag, she departs from a false-solidarity, mediatized, by humanitarian gestures in Balkans, but these acts not only are not real, are counter-productive for the same goals she pursue. Sontag, at some extent, acts in complicity with status quo. The splendid coverage she receives, represents not only hypocrisy but a hidden patriotism that does not defy on American partisanship. (Baurdillard, 1985; 1986). What intellectual do not appreciate is terrorists do not hate US, because she is the freest, prosperous, wealthier and democratic republic of the world (values imposed by means of war and violence) but they received everything from US. In other terms, Baudrillard explains masterfully how hate is caused by humiliation not by exploitation. US and West colonized the Middle East mind from long time ago. 9/11 exhibits a reactionary response to the humiliation inflicted by global powers. Nor Sontag neither Chomsky seems to realize they are using suffering to populate the American values in the world. Their inabilities to see the problem of democracy, or Anglodemocracy as well as the asymmetries given by globalization, allude to a much broader change in the ways of production. Nation-state and capitalism are inextricably intertwined.

Other interesting view-point is given by Paul Virilio (2010) who complemented the thoughts of Baudrillard. Is the technology responsible for human disasters?. He responds to this that technologies and mobilities not only have created new forms of displacements, but also have blurred the relation between time and space. As a result of this, people have full access to any geographical point of this globe in hours. The time of waiting has changed forever. Travelers now are moved by the indifference and visual consumption. There is not genuine contact in the visited lands. The events in the past formed history as a continuation of ordered facts, but global transportation and communication technologies make anew kind of real time in which people can no longer synchronize watches. Citizens have been transformed in consumers. History has been emptied into a fragmentation of events, dispersed globally and broadcast repeatedly. The function of modern university is not producing knowledge any-longer. Now, the university is producing experts conducive to the insurance policies and market demands. Virilio argues that everything happens at the same time in the hyper-reality without a logical sequence. The world stage is represented outside the planet, in an exo-earth. The days of Science, as an all-encompassed instrument based on rational understanding, has changed. Transformed in an exo-science that promotes the simultaneous globalization of fear, whilst biology and astronomy are eclipsed by the "eternal present". Virilio emphasizes the "mea culpa" of science for its failure to create an ethic of life. Based on the belief that the global warming is not reversible in the short-run terms, science should explore issues from the perspective of homeland safety and security. To be protected, big corporations, banks, and the capitalist elite call climatologists and geographers (experts) to design catastrophe simulation software that provides some information about where the next disaster will take hit. In this vein, a new profession is rising, the "economic-disaster-modelinggeek". This expert seems to be more interested in finding and eliminating the risks to businesses, or finding ways to profit from such risks, than in protecting the environment. The philosophy of the science is today determined by the logic of digital screens. The simulation of future that characterizes the digital world has replaced the daily life (Virilio, 2010).

What is important to debate here is to what an extent the Science has become in an irreducible ally of market. Not only the software, but the geologist today are posed to the assistance of insurances companies, to know where nature will beat tomorrow. The problem of ecological risk seems not to be of extreme importance of experts, unless by the economical losses they generate. The modern science lacks of criticism to discern the information it produces. More interested in anticipating to the future than understanding the past, the science coupled to technology, simulates reality to mitigate risks. In this respect, Virilio and Baudrillard agree. 
"We might note a recent project whereby detection of major risks is reversed, since the computer in question is involved in producing said major risks. At the end of 2006, IBM effectively decided to build the most powerful super calculator in the world. To do so, it will use processors capable of up one million billon operations per second, accelerating by as much the reality of the disastrous progress in weapons of mass destructions... which prompts personal question: after having resorted to meteorologists and other climatologists to calculate the economic risk of catastrophe, will the insurance and reinsurance companies one day have to call on the army and their new strategists to detect major ecological risk of nuclear proliferation" (Virilio 2010: 18).

Although the specialized literature up to date has focused on the probabilistic nature of risk, it is socially negotiated and communicated. Skoll \& Korstanje (2012) said that risks are conducive to economic production. At some extent, risks only can be mitigated once occurred, not before. This links mind to future. If a correct decision, is made in basis with a scientific evaluation of risks, specialists admits the negative effects of disaster can be reversed. Rather, risks seem not to be a result of human's ignorance but a gradual process that allowed the replication of capital. The dangers travellers would face to carry goods from one to another point of the globe (from eighteenth century onwards) determines the final transaction price. Under this viewpoint, risk was functional to the expansion of mercantilism and later capitalism. Besides, each society develops particular forms of living democracy according to a sentiment of autonomy that alternates between efficiency and institutionalism. Given this argument, Skoll and Korstanje (2012) explain that risk works by the introduction of a text, a discourse, mediated, produced and defended by experts. While some properties may be widely exchanged depreciating their value, others are banned but strongly requested. The value of the latter goods is so exorbitant that they become inalienable possessions. Furthermore, those actors that monopolize the possession of these taboogoods enhance their prestige and gain further legitimacy than others. This generates an economic asymmetry between the citizens. Validated only in the future, lay-people only may buy for insurance-related protection prior to the disaster takes room. As Baudrillard and Virilio put it, risks enable some tactics of capital reproduction based on the future. As a result, the present and history do not exist anymore. The disaster-related news leads people to mass-consumption, while nation-state introduces nationhood to legitimate the use of violence in case of internal dispute.

In her book Unspeakable Violence, Nicole Guidotti-Hernandez alerts about the disciplinary instrument employed by state in borderlands to domesticate the otherness. In doing so, the selective memory and the belief of nationhood awakening were of paramount importance. Nation states are formed under process of differentiation and its economic re-organization of territory. The centre of hegemony, like ideology, works by the control of what we denominate authenticity. Mexico, for instance, promoted an image to the world based on the multiculturalism and respect for aborigines. However, less is said about how the government reserves the monopoly of force to discipline some other peripheral ethnicities. Although, The Aztec (lo indio) heritage is being selected to denote greatness, power and intervention, other indigenous groups are relegated to secondary positions (Guidotti-Hernandez, 2011). The Guide-texts that are offered to international visitors not only trivializes the history, but inflicts an unspeakable violence to legitimate the cultural values of elites.

Last but not least, the events in Japan makes one forget the causes and the effects of other catastrophes of the same magnitude as that of Haiti (whose circumstances are similar (¿a qué) or of Chile, New Zealand or New Orleans. In that context, culture fills the vacuum generated by modernity through which each actor and member of the group receives a value (identity) that distinguishes him/her. Personal value is assigned to each citizen by means of his/her salary. We connect this personal value to the person's capacity to be able to operate with other outside risks, by means of providing professional advice. Thus, when we affirm that an accident impacts the market we are not only harmed but we underestimate its internal logic. The accident gives value to the product. Natural disasters or manmade disasters are valued in the market place according to the specific demands of the consumer. It is not the same to travel to ground 0 where the Twin Towers were located as to go to location $\mathrm{X}$ on the globe without media representation.

The importance of Baudrillard for disasterrelated Research has been ignored by some specialists, in part because few risk-related researchers are aware with philosophical texts. 
Epistemologically speaking, Baudrillard was a pioneer who envisaged the connection between risk and future by the sufficient perspective to present an all-encompassing framework to understand the psychological impacts of disasters in our daily life. Baudrillard's studies influenced the work of many other philosophers and sociologists, interested in risk research as Niklas Luhmann or Anthony Giddens.

\section{The Episteme of Risk}

Although risk perception studies note highly complex algorithmic mathematical categories, there is no fundamental epistemology to study risk from a qualitative perspective. Unfortunately for researchers in tourism who are interested in studying risk phenomenon the threat of the natural disaster, these scholars do not publish their studies from the qualitative side. From projection techniques to diverse ethnographies or content analysis there exists a never-ending variety of techniques that permit a scientific study of risk in such approved by consensus categories and socially constructed that escape the logic of a number to take root in the technical language. (Luhmann, 2006). In accordance with the development of the German sociologist Niklas Luhmann, one of the characteristics of risk is that despite being placed in a limited possibility of being avoided, it also becomes a product within the decision making process. An airplane crash, the stealing of luggage from an airplane, or a suicide bombing among others provides the subject choices of risk. The individual assumes his/her own risk when s/he participates in the decision making process that results in the expected or not expected results. Events are presented outside of the subject's decision-making process must be understood as a threat or danger. This is one of the most common conceptual perceived theoretical errors as applied to travel. However, as we shall see in the following section when the subject avoids the formal professional channels risk then increases.

\section{From Disasters to Cultural Travel}

The Administrative council of the FCAJ (Fundación Cultural Argentino-Japonesa/ JapaneseArgentine Cultural Foundation) headquartered in Buenos Aires' Japanese Garden (Jardín Japonés) organized a cultural trip to Japan to take place in 2012, The trip was organized prior to the country's 2011 earthquake. The event (earthquake) did not cancel the trip but postponed it. However, the way in which it was organized changed considerably. This travel, post disaster context, engendered a risk associated to the exposure of radioactivity. Defying more than four decades of literature in risk avoiding studies, what in moral circumstances would be a motive of rejection, here was the steppingstone of travel.

The pamphlet or flier published by this association makes mention of the quantity (quantification of the desire as an argument for sale) of questions that the association had received with respect to the potential trip:

"A bit more than a month had passed since the terrible event in Japan, we gathered our forces to revisit the subject about the Cultural Trip to Japan to occur in 2012 and answered some of the questions. We received in those days a visit from the Ms. Srta. Mariko Hamamoto,a member of the Advisor Council of the Foundation's administration who currently was residing in Kyoto. She transmitted to us information about the current situation in Japan. With these concrete data, the FCAJ was able to evaluate the subject and decided to continue the trip".

Although the trip was planned prior to the earthquake, FCAJ could not avoid the fact that the situation had changed. The cultural trip to Japan was based on the ideal of "brotherhood" between communities and as such this implied sharing of the risks. The narrative of the trip to Japan, however, presents specifics that distinguish it from other narratives. The mediated image of disaster, the virtual danger, the professional advice and the culture are current matters when we read the official letter of the FCAJ.

Likewise, it is of interest to note that the trip's tours had been scheduled so as to maintain a considerable distance from the Fukuyama nuclear plants. As for the "rapid recovery" of Japan, that the Japanese descendents longed for, is added the layout of an centerfold showing places to where they were making a pilgrimage. The trip literature indicated that despite everything that had happened it the danger had not increased over other excursions that the FCAJ had previously made to Japan. The organizers indicted a high degree of professionalism. For example they informed the travelers that the trip would go through Canada rather than the United States to avoid visa issues and were 
there to be any danger that the trip would then be cancelled.

\begin{abstract}
"The travel plan remains without modifications. For everyone's tranquility, we are informing you that the cities to be visited, according to our itinerary are some 500/600 kilometers to the south of where the tsunami struck and where the explosion at the Central Nuclear Electrical plant occurred (see details on map below) We are confident in a rapid Japanese recovery. We further want to inform you that our first meeting of about our Cultural Trip to Japan was a complete success, last Friday (March 4). We thank everyone who attended and we remind you of the topics to be discussed." ..."Two possible itineraries have been handed out; these are the ones that the travel agencies with which we are working have given to us. Once the final group is formed the final itinerary will be developed. Although the majority of those interested are confident in that which has been proposed until now. With respect to the travel route, we will try to avoid the USA due to difficulties in obtaining visas. A possible route is through Canada. Getting a Canadian visa is a simple process. (Remember that these procedures are your responsibility) We calculate (including time on board, layovers) more than 30 hours of travel until we reach Japan. Once we have ten confirmed reservation the trip is confirmed".
\end{abstract}

A second aspect of tourism must be the cost-benefit analysis. The FCAJ, just as any organization that is sponsoring group travel must weigh the trip's desired results, maximize earnings and minimize losses. Toward this end the FCAJ had to take into account security concerns, and assure the traveling public that they would be safe while demonstration cognizance of the risks involved. Like the Sontag's trip widely criticized by Baudrillard, there is nothing real in this travel. Tourists want to feel an outstanding experience, previously labeled by Television. At a first glance, they seem to be risk-taker travelers, but in fact, the cultural adventure is fully safe. Commoditized, framed and sold before starting, the cultural travel may be equaled to what Baudrillard calls pseudo-events.

The Baudrillard model is helpful in understanding that cultural consumption is related to the rational estimates of the outcomes. The traveler must evaluate the costs and benefits emphasizing his/her own ontological security; in such a process culture becomes secondary in importance to security. Yet it is culture that is being consumed and cannot be overlooked. The FCAJ trip demonstrated that unfortunate incidents, the pain of others and/or catastrophes in many cases do not break the logic of consumption but when combined with nationalism may add to its potential. In a hyper reality risks are not real, are figured by the media. Modern man seeks the spectacle and the unique and yet seeks a deepening of his/her cultural roots. We see this exemplified in the following paragraph of the FCAJ missive: "We look forward to your confirming that you will be on this spectacular Cultural Trip"

The spectacle has two possible semantic definitions. The first is connected to "differences" that is to say, that trip is characterized not only by being in an area of supposed radioactive danger, but also by the unique Japanese. Secondly, the abnormal situation in which the trip was undertaken is for many exceptional and this re-enforces the need to maintain limits between a superlative ego and the radicalization of the other. In this context, the voyage can only be carried out if the members have all paid which indicates a subordination of the cultural with respect to the financial economic aspects.

"We emphasize that this trip is organized by FCAJ, that it is NOT a tourism business. We count on the experience of more than 30 trips made by the Federation's president. Moreover, one of the members of the Foundation's Executive Council currently lives in Japan, and can guide us directly on subjects such as those mentioned at our meeting. (Potters, important painters of sumi-e, kabuki theater, calligraphy, martial arts, government themes etc)”.

Note that the professional advice given by the travel agent in the organization of tours has in this case been relegated to being less important or not important at all. The organizers suggest that the trip to Japan will be carried out in a secure environment while doing without an external organization. The FCAJ notes that it has conducted some thirty trips to Japan and has the assistance of one of its members who is a native of that country and who currently lives there. Thus through shared knowledge and enhanced communication the FCAJ has eliminated the necessity of a travel agent and demonstrates assumed risk (as an example of the insurance company) without the perceived need for professional advice.

The ACAJ literature stated subliminally that a tourism agency might detracte from the 
seriousness of the cultural visit and for this reason who better than the ACAJ to organize the voyage? As in this case and in other cases, the lack of professional advice in the tourism organization, that is to say the decline of the travel agent, is present as a characteristic of the process of re- liableness on modernity and the gathering of individual risks as understood by Beck and Giddens. As professional advice declines individual risks become greater. The experiences along with other fundamental aspects of professional advice are explained by the historic role that advisors have provided in the life of men, from the ecclesiastic confessors to the therapists and travel agents. All of them have fulfilled a similar function, the adding knowledge to the sense of possibility for civilization.

Reviewing the institutional letter, analyzed and sent by a Japanese association permits us to understand sociologically the following elements.

1) Modern travel and tourism is found rooted in a finical-economic matrix whose characteristics subordinate the social but do not eliminate it entirely.

2) Travel needs a symbolic construction, a narrative with sufficiently attractive and powerful to assure the travelers' interest. This criteria has varied throughout the centuries, however in our age it is characterized by being anchored in the cultural, in tradition and in folklore.

3) The indigenous does not only represent a greater group cohesion as in the case of the Japanese tour as it mentions the privilege of "being Japanese", but also prearranges as a product ready for collective consumption. The culture absorbs the anguish of the unknown by means of the building of risk.

4) For the exposed, the danger or the potential danger that the Japanese earthquake represented and the ensuing difficulties in that country to deal with its problems in its radioactive plants play an ambiguous role. On one hand, they attract a Japanese public hurt/upset from the tragedy in a kind of rapprochements, while on the other hand, they alienate certain spaces that are now off-grounds. The tour is possible thanks to this combination of attraction and contained danger

It is not strange to observe as in moments of emergency and/or natural disasters, that diverse mechanism come forth that help these groups to understand that which is happening to avoid disintegration. As explained by Baudrillard in his vast bibliography, nationalism and the proclivity for consumer-culture are the social mechanisms whose function lies in understanding the world's events and making sense of them. Tragedy supposes a radical extermination, but at the same time individual and group strength to overcome the same. It is in this context, national pride is demonstrated soon after an event of such proportions as an earthquake or tsunami. What we find in play is the necessity of making sense of something that appears to make no sense. The missive's message was simple stating: yes a great part of Japan has been destroyed with a high cost in human life and materials, the survivors realize that despite all the community is still standing.

\section{Conclusion}

After review, we consider that Baudrillard texts would be of importance for the risk related research in next decades. They allude to a fertile ground to study the connection between cultural entertainment, media and nationalism. Further, Baudrillard reminds us that the exacerbation of the group strength for going forward toward the reconstruction and the role of nationalism are important at the time of confronting reality. That in that instant are where the national and the traditional converge and the market as the capable entity of organizing individual passions and turning them (or sublimating them) in established relationship modes (Baudrillard, 1995; 1995b). The analyzed document, issued by ACAJ shows any travel, even the cultural one, is ascribed to an economical matrix, which delineates the boundaries between safe and unsafe geography. Experts and specialists, in this case the tour-operators suggest to travelers who is the best options for achieving a unique experience, but this does not mean such an experience is real. The national-being represents serious attractions for travels in a type of brotherhood, which is not altered even in spatial distance. Being Japanese not only is a reason of pride, because after the quake, Japan is still working to recover the obliterated industries, schools and households, but alluding to a sentiment of ethnocentrism respecting to the rest of the world. Following the explanation of $\mathrm{C}$. Lasch, this process of victimization is narcissistic, closed to the dialogue with others. As a result of this temporal blindness, where the real causes of Fukuyima's tragedy are not debated, will be a fertile source for a next disaster. The concept of hyper-reality 
coined by $\mathrm{J}$ Baudrillard is of paramount importance to expand the current understanding in how any disaster sets the pace to the other. This setting is conductive for status quo to introduce radical changes that otherwise would be rejected by public opinion. After a catastrophe, capitalism offers higher new recycled buildings, taller skyscrapers, further modern infrastructures, faster mobile technologies. The important aspect that lies below the surface in these processes is the need to be able to create future order out of chaos. The market recreates new fictions by which possibility of new disasters may be borne. In this context, the disaster can be transformed also into a symbolic mediator and product of consumption giving rise to what (tourism) specialists call "Dark Tourism". Modern society not only sells "tranquility and security" to its consumers, but also through crisis management gives birth to a new product. Tourism, culture and the travel industry are part of the never-ending cycle of creation that perhaps first started with the Big Bang. Thus, we are in the presence of "the end of disasters" as events really structured that provide social meaning. Today catastrophes are socially and journalistically enshrined in the world of consumerism. After all, what nobody discusses is, as noted Voltaire, earthquake does not kill people, buildings do ... disasters are human inventions, produced by human intervention into environment.

\section{References}

Baudrillard, Jean

1985 "Intelectual Commitment and Political power: an interview with Jean Baudrillard". Thesis Eleven.

1986 America. New York, Veso.

1995a The systems of the objects. Mexico: Siglo XXI.

1995b The Gulf War Did Not Take Place. Sydney:

Power Publications

2000 Pantalla total. Barcelona, Anagrama.

2001 Imposible Exchange. New York, Verso.

2002 Screened out. New York, Verso.

Bauman, Zygmunt

2008 Miedo Líquido: la sociedad contemporánea y sus miedos líquidos. Buenos Aires: Paidos.

Beck, Ulrich

2006 La Sociedad del Riesgo: hacia una nueva modernidad. Buenos Aires: Paidos.

Berbeglia, Enrique

2002 "Catastrofismo y Control". En Documental Laboris. Problemática Actual de la Psicología Social. Buenos Aires: Leuka. 179-195
Bianchi, Raoul

2007 "Tourism and The Globalization of Fear: analyzing the politics of risk and (in)security in global travel". Tourism and Hospitality Research 7(1): 64-74.

Bledstein, Burton

1978 The Culture of Professionalism. The middle class and the higher education in America. Nueva York: Norton.

Birtchnell, Thomas y Buscher, Monica

2011 "Stranded: an Eruption of Disruption". Mobilities 6(1): 1-9.

Coulter, G.

2012 Jean Baudrillard: from the Ocean to the desert or the Poetics of Radicality. Gerry Coulter. New Smyrna Beach, Florida: Intertheory Press

Douglas, Ngaire

1997 "The Fearful and the Fanciful: early tourists perception in westearn Milanesia". The Journal of Tourism Studies 8(1): 52-60.

Elías, Norbert. y Dunning, Erich

1992 Deporte y Ocio en el Proceso de la Civilización. Buenos Aires: Fondo de Cultura Económica.

Fielding, Robert et al

2005 "Avian Influenza Risk Perception, Hong Kong". Emerging Infectious Diseases 11(5): 677-682.

Giddens, Anthony

1991 Modernity and Self-Identity: Self and Society in the Late Modern Age. California: Stanford University Press.

1999 Consecuencias de la Modernidad. Madrid: Alianza Editorial.

2000 Un Mundo desbocado. Los efectos de la globalización en nuestras vidas. Madrid: Taurus

George, Babu, Inbakan, Robert. y Poyyamoli, Gopalsamy

2010 "To Travel or Not to travel: towards understanding the theory of nativistic motivation". Tourism, an international interdisciplinary Journal. Vol. 58(4): 395-407.

Guidotti-Hernández, N.

2011 Unspeakable Violence. Remapping Us and Mexican National Imaginaries. North Caroline, Durham: Duke University Press.

Kaelber, Lutz

2007 "A Memorial as Virtual Trauma-escape: darkest tourism in $3 \mathrm{D}$ and Cyber Space to the gas Chambers of Auscwitz". Ertr, e Review of Tourism Research 5(2): 24-33

Korstanje, Maximiliano and Busby, Graham 2010a "Understanding the Bible, as the roots of Physical displacement: the origin of Tourism". E-Review of Tourism Research, 8(3): 95-111. 
Korstanje, Maximiliano \& Skoll, Geoffrey

2012 "Risk Totems and Fetishes in Marx and Freud". Sincronia. 1(1): 1-20

Korstanje, Maximiliano

2010 "Commentaries on our new ways of perceiving Disasters". Disaster Resilience in the Built Enviroment 1(2): 241-248.

Korstanje, Maximiliano

2011 "Swine Flu in Buenos Aires: Beyond the Principle of Reisilience". International Journal of Disaster Resilience in the Built Enviroment. 2(1): 59-73

Larsen, Svein

2007 "Aspects of a Psychology of the Tourist Experience". Scandinavian Journal of Hospitality and Tourism 7(1): 7-18.

2009 "What Tourists worry about: construction of a scale measuring tourist worries". Tourism Management 30: 260-265

Lasch, Christopher

1999 La Cultura del Narcisismo. Santiago: Editorial Andrés Bello.

Lash, Scott. y Urry, John

1998 Economías de Signo y Espacio: sobre el capitalismo de la postorganización. Buenos Aires: Amorrortu Editores.

Lennon, J. and Foley, M.

2000 Dark Tourism: The attraction of Death and Disasters. London: Thomson Learning.

Lew, Alan

1987 A framework of tourist atraction Research. Annals of tourism Research, 14(4), 553-575.

Luhmann, Niklas

2006 Sociología del Riesgo. México: Universidad Iberoamericana.

Marx, Leo

1994 "The Idea of Technology and Postmodern Pessimism". In Technology, Pessimism, and Post-Modernism. Ezrahi, Y, Mendelsohn, E. and Segal. Dorderecht, H. Kluwer Academic Publishers. 11-28.

O'Rourke, Peter

1988 Holidays in Hell. London: Picador Ed.

Pippin, Robert. N.

1994 "On The Notion of Technology as Ideology: prospects". In Technology, Pessimism, and Post-Modernism. Ezrahi, Y, Mendelsohn, E. and Segal. Dorderecht: H. Kluwer Academic Publishers. 93-113.

Poria, Yaniv

2007 "Establishing Cooperation between Israel and Poland to save Auschwitz concentration camp: globalizing the responsibility for the Massacre". International Journal Tourism Policy 1(1): 45-17.
Quarantelli, E. L.

2006 "The disasters of the $21^{\text {st }}$ century: a mixture of new, old, and mixed types". Disaster Research Center, Preliminary Paper 353. University of Delaware United States

Ryan, Chris

2005 "Dark Tourism - an introduction". In C. Ryan, S Page and M. Aitlen. Taking Tourism to the limits: issues, conceptys and managerial perspectives, (pp. 187-190). Oxford: Elsevier.

Ryan, Williams

1971 Blaming the Victims. New Jersey: Vintage Books.

Seaton, A. V.

1996 "Guided by the Dark: from Thanatopsis to Thanatourism. International Journal of Heritage Studies 2(4): 234-244

1999 "War and Thanatourism: Waterloo 18151914". Annals of tourism Research. 26(1): 130158.

2000 "Thanatourism: entry". In J. Jafari, Encyclopedia of Tourism. London: Routledge.

Sojberg, Lennart

1999 "Risk Perception by The Public and By Experts: a dilemma in risk management". Human Ecology Review 6(2): 1-9.

Stone, Phillip

2005 "Dark Tourism Consumption - A Call for Research”. Ertr, E-Review of Tourism Research 3(5): 109-117.

2011 "Dark Tourism and the cadaveric Carnival, mediating life and death narratives at Gunther Von Hagen's Body Worlds". Current Issues in Tourism. In press. 1-17.

Tang, Cheong. T y Wong, Koi. N.

2009 "The SARS epidemic and international visitors arrivals to Cambodia. Is the impact permanent or transitory?". Tourism Economics, 15(4): 883-890.

Urry, John

2001 "Globalizing the Tourist-Gaze". Proceeding cityscapes Conference, Graz, Austria. November.

2007 "Introducción, Culturas Móviles". En Viajes y Geografías. Zusman, P. Lois, C y Castro $\mathrm{H}$ (compiladoras). Buenos Aires: Prometeo, 17-31.

Virilio. Paul

1991 La Inseguridad del Territorio. Buenos Aires, La Marca.

2007 Ciudad Pánico: el afuera comienza aquí. Buenos Aires: libros el Zorzal.

2010 The University of Disaster. Oxford: Polity Press

Wenge, Chris. O.

2007 "Razones para Viajar". Factótum. Revista de Filosofía. Número 5. Edición Viajes y Via- 
jeros. Disponible en http://www.revistafactotum.com/. 88-91.

Zizek, Slavoj

(2011) "El Estado de Emergencia económica permanente". Edición Le Monde Diplomatiqué. A Diez años del 11 de Septiembre. Cómo Cambió el mundo. Buenos Aires: Capital Intelectual, 203-208. 